NASA Technical Memorandum 107514

AIAA-97-3143

\title{
Dynamic Simulation of a Wave Rotor Topped Turboshaft Engine
}

R.B. Greendyke

Texas A\&M University

College Station, Texas

D.E. Paxson

Lewis Research Center

Cleveland, Ohio

M.T. Schobeiri

Texas A\&M University

College Station, Texas

Prepared for the

33rd Joint Propulsion Conference and Exhibit cosponsored by AIAA, ASME, SAE, and ASEE Seattle, Washington, July 6-9, 1997

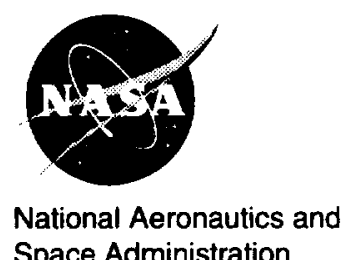

Space Administration 


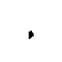




\title{
DYNAMIC SIMULATION OF A WAVE ROTOR TOPPED TURBOSHAFT ENGINE
}

\author{
R.B. Greendyke* \\ Texas A\&M University \\ College Station, Texas, USA \\ D. E. Paxson ${ }^{\ddagger}$ \\ NASA Lewis Research Center \\ Cleveland, Ohio, USA \\ M.T. Schobeiri ${ }^{\dagger}$ \\ Texas A\&M University \\ College Station, Texas, USA
}

\begin{abstract}
The dynamic behavior of a wave rotor topped turboshaft engine is examined using a numerical simulation. The simulation utilizes an explicit, onedimensional, multi-passage, CFD based wave rotor code in combination with an implicit, one-dimensional, component level dynamic engine simulation code. Transient responses to rapid fuel flow rate changes and compressor inlet pressure changes are simulated and compared with those of a similarly sized, untopped, turboshaft engine. Results indicate that the wave rotor topped engine responds in a stable, and rapid manner.

Furthermore, during certain transient operations, the wave rotor actually tends to enhance engine stability. In particular, there is no tendency toward surge in the compressor of the wave rotor topped engine during rapid acceleration. In fact, the compressor actually moves slightly away from the surge line during this transient. This behavior is precisely the opposite to that of an untopped engine. The simulation is described. Issues associated with integrating CFD and component level codes are discussed. Results from several transient simulations are presented and discussed.
\end{abstract}

\section{Introduction}

Wave rotors represent a promising technology for use as high pressure, high temperature topping cycles in gas turbine engines. ${ }^{1-3}$ Predicted steady state performance benefits of wave rotors topping small, current technology turboshaft engines indicate a reduction in specific fuel consumption of up to $16 \%$ from the untopped engine, with a similar increase in engine power. $^{2}$ Predicted rotor metal temperatures are well below the combustor discharge temperature, and the rotor rotational speed is considerably less than that of a

\footnotetext{
"Research Assistant, Senior Member AlAA

$\ddagger$ Aerospace Engineer, Member AIAA

${ }^{\dagger}$ Professor, Member AIAA

Copyright 1997 by the American Institute of Aeronautics and Astronautics, Inc. No copyright is asserted in the United States under Title 17, U.S. Code. The U.S. Government has a royalty-free license to exercise all rights under the copyright claimed herein for government purposes. All other rights are reserved by the copyright owner.
}

conventional turbomachinery spool performing the same topping function.

Numerical simulations of wave rotors indicate that offdesign performance is good and that transient response to disturbances is stable and rapid compared with conventional turbomachinery. ${ }^{4}$ Until this investigation however, transient wave rotor simulations did not model the interactions with surrounding turbomachinery (e.g. upstream compressor and downstream turbines) that would actually occur in a topping cycle configuration. Full, steady state, wave rotor topped engine cycle deck investigations have been performed but these can only state whether the engine will operate at one point or another, they cannot answer questions regarding transient response, stability, or controllability. ${ }^{4.5}$ For example, in conventional compressor-combustorturbine engines rapid fuel flow rate changes are restricted due to compressor surge limit considerations. Is there a similar limitation for wave rotor topped engines? How does the system respond to compressor inlet perturbations?

This paper presents the results from a numerical simulation developed to address these and other questions concerning the dynamic integration of wave rotors with surrounding turbomachinery. The simulation was created by combining a dynamic, component level, implicit engine code, GETRAN, ${ }^{6,7}$ with a dynamic, explicit, CFD based, wave rotor code ${ }^{4}$ into a single integrated software simulation. The two codes and their integration into a single code are briefly described. The results from several simulations are then presented and discussed. Comparisons are made between simulations of wave rotor topped and untopped gas turbine engines during similar transient operations. The paper concludes with some remarks regarding implications of the results, and possible future improvements to the simulation. 


\section{Simulation Description}

Both the engine code and wave rotor code have been described extensively in the literature. ${ }^{4-7}$ As such, only brief descriptions will be given below.

The GETRAN code is a one-dimensional, component (or turbomachinery stage) level, generic gas turbine engine simulation. Due to its highly modular structure, it can simulate nearly any combination of conventional gas turbine components such as turbomachinery, combustors, diffusers, ducting, nozzles, etc. The onedimensional nature of the code allows great flexibility in the design process and in the simulation of transient operations. Code modules, each simulating a different engine component, communicate boundary conditions by the use of coupling plena (volumes). The plena transfer information about total pressure, total temperature, mass flow, and other physical conditions from one engine component to the next. The plenum module imposes the time dependent, nonlinear conservation equations of mass momentum and energy between components. Time integration is done implicitly, ensuring stability for the typically stiff system of equations.

The second code, heretofore called WR1D, is an explicit one-dimensional CFD based wave rotor simulation which tracks the gasdynamic processes in each of the passages of the wave rotor as they rotate past the various stationary ports. Familiarity with the wave rotor and its operation is assumed in this paper; however, for reference, a schematic drawing of a wave rotor is shown in Fig. 1. The WRID code, though relatively simple because it is one-dimensional, has experimentally validated sub-models for most of the major loss mechanisms found in wave rotors. These make it capable of fairly realistic simulation. Explicit time integration is used in this code because of the small time steps required to accurately capture the gasdynamic processes in the passages.

\section{Integrating the Codes}

Because of the general component-plenum structure of GETRAN, it was relatively simple to incorporate the explicit WR1D simulation code into the implicit GETRAN code. GETRAN does not iterate on discrete flowfield points or volumes as do conventional CFD codes. It is the plena conditions that are iterated upon during a given time step until the governing (difference) equations are satisfied. For the WRID code, on the other hand, plena information are used as boundary conditions and port flow information is computed at each of its time steps. Typical GETRAN time steps are

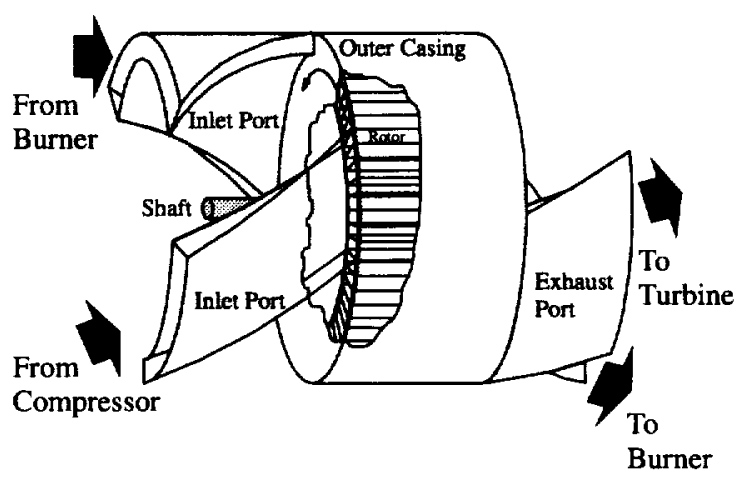

Figure 1 Schematic wave rotor

several orders of magnitude larger than those in the WRID code. Thus, with the WRID simulation incorporated as a GETRAN component (e.g. a callable subroutine module), GETRAN simply supplies the WR1D code with it current 'best guess' of plena conditions. The WR1D code then integrates over the GETRAN time step and returns the port flow information (e.g. mass flux, enthalpy flux, etc.) to GETRAN.

The "Gattling gun" nature of the wave rotor's individual passages presented the only difficulty in the merging the two codes. The WRID code operates on time scales which resolve the rapid fluctuations in flow conditions as the wave rotor passages open and close to the various ports. Typically, these fluctuations are highly damped a short distance down or upstream from the rotor face in any given duct leading to or from the wave rotor. The WR1D code does not model these ducts, so the fluctuations are not damped. The fluctuations made it difficult for the GETRAN iteration to converge. As such, it was necessary to use a simple data smoothing algorithm (e.g. an averaging) on the results returned by the WR1D subroutine. The averaging time was chosen so that accuracy was maintained over the time scales of interest in the simulations.

\section{Computing Requirements}

The integrated simulation code was very CPU intensive. Even though a very course spacing of 10 numerical cells per wave rotor passage was used, the small time step of the WR1D code $\left(6.25 \times 10^{-6} \mathrm{sec}\right.$.) required considerable CPU usage in and of itself. The implicit nature of the GETRAN code requires several iterations per GETRAN time step $\left(8.00 \times 10^{-4} \mathrm{sec}\right.$.), and therefore several calls are made to the WRID routine at each GETRAN time step, thereby multiplying the problem. Typical simulation requirements were 10 hours of CPU time for 1 second of real time on an SGI Power Challenge. 


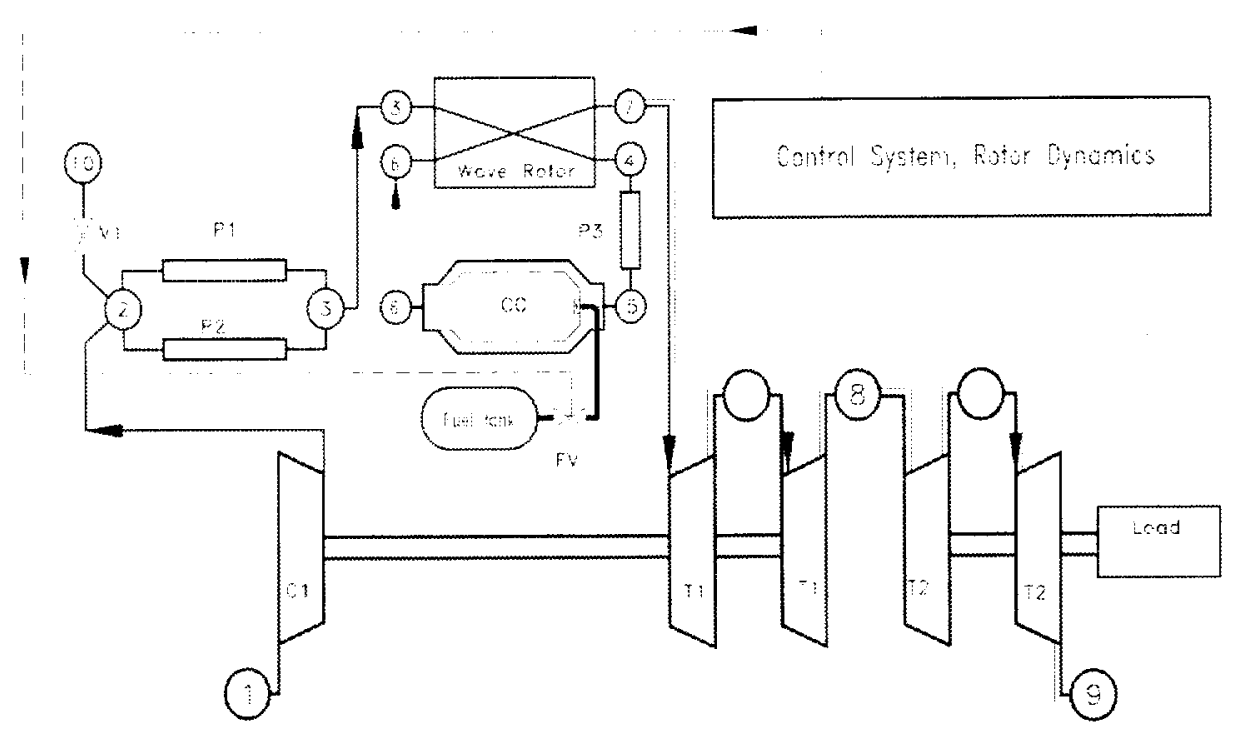

(a)

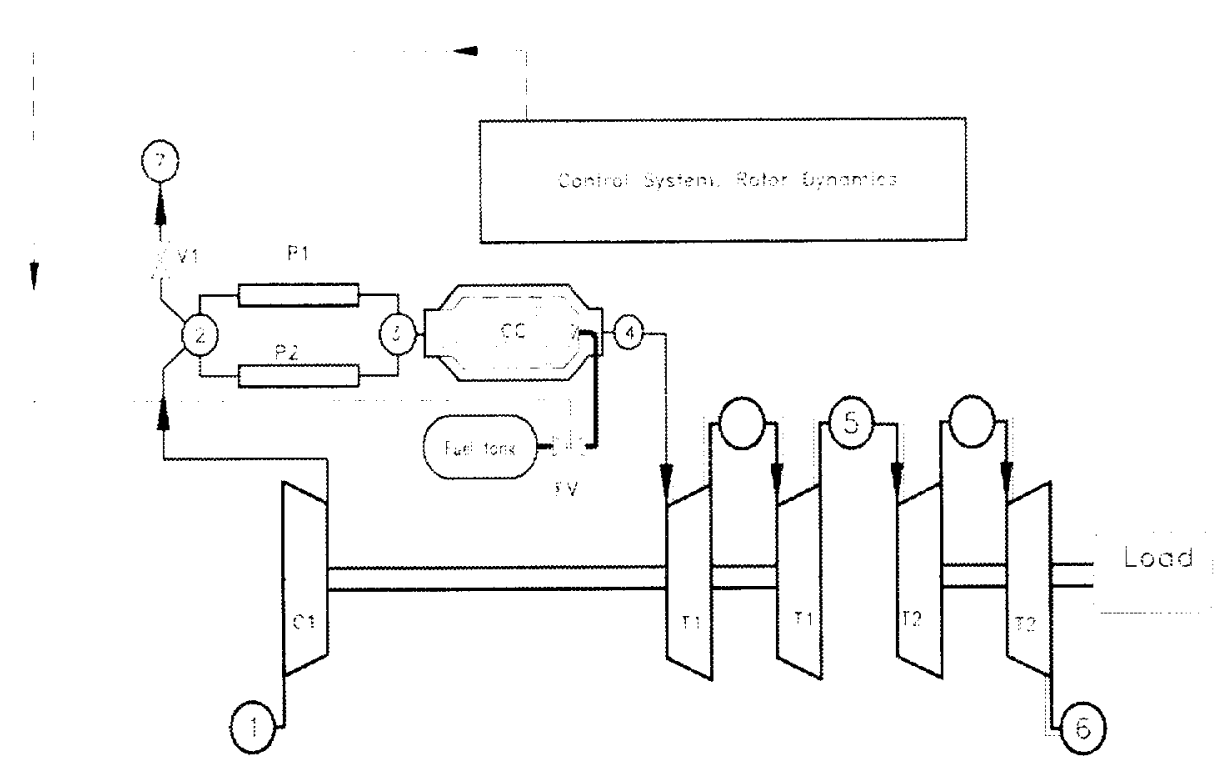

(b)

Figure 2 Simulation schematics, with relevant component numbering for: (a) wave rotor topped, and (b) untopped engines

\section{Methodology}

The methodology for this investigation was relatively simple. Two basic engine designs were created for study based upon a small turboshaft engine. Schematic layouts for the two designs are shown in Fig. 2. Both designs had identical design inlet mass flow rates, compressor pressure ratios, and high pressure turbine inlet temperatures. These are listed in Table 1. Both designs also contained identical design point component efficiencies, and overall compressor performances, and shaft moments of inertia (rotor moments were estimated). The first design, Case 1 , was a wave rotor topped configuration. The second design, Case 2, was a baseline configuration with no wave rotor. Details of the Case 1 wave rotor design has been described in the literature. ${ }^{4.5}$ The wave rotor was designed to be selfdriven, that is, requiring no external drive motor or transmission. In the present investigation however, the rotor was assumed to run at constant speed throughout 
Table 1 Compressor and Turbine Design Specifications

\begin{tabular}{lll}
\hline \hline & Case 1 & Case 2 \\
Design Mass Flow, kg/s & 2.168 & 2.168 \\
Compressor Pressure Ratio & 7.77 & 7.77 \\
HP Turbine Pressure Ratio & 2.92 & 2.92 \\
HP Turbine Inlet Temperature, K & 1329 & 1327 \\
HP Turbine Efficiency & 0.86 & 0.86 \\
LP Turbine Pressure Ratio & 3.26 & 2.49 \\
LP Turbine Inlet Temperature, K & 1056 & 1052 \\
LP Turbine Efficiency & 0.86 & 0.86 \\
\hline
\end{tabular}

all of the transient operations. The power required to maintain constant rotor speed is very small (e.g. less than $0.5 \%$ of the power turbine output).

The compressor and turbines were simulated in the GETRAN code by use of the global compressor and turbine subroutines available in the code. ${ }^{6}$ These subroutines model component performance (e.g. compressor or turbines) using mathematical curve-fits to the maps. The compressor performance maps and turbine design point efficiencies used for the curvefitting were obtained from a steady-state cycle deck simulation. ${ }^{8}$

\section{Steady State}

Both Case 1 and 2 were run until a steady state (or equilibrium) condition was obtained. The equilibrium air mass flow through the Case 1 combustor was a nominal $3.35 \mathrm{~kg} / \mathrm{s}$, or $54 \%$ higher than that of Case 2 . This was consistent with specified design point values. Similarly, pressures and temperature in the plena associated with the wave rotor ports were well matched to design specifications. These results indicated that the simulation was operating correctly, at least in steady state. The shaft output of the Case 1 low pressure power turbine was approximately $0.657 \mathrm{MW}$. The nontopped Case 2 power output was $0.527 \mathrm{MW}$, giving the Case 1 configuration an expected $24.7 \%$ increase in power.

It is noted that the compressor design for Cases 1 and 2 has a small amount of bleed flow which would normally be used for cooling the high pressure turbine (HPT). Due to the addition of the wave rotor in Case 1, the bleed flow no longer has enough pressure to be used for HPT cooling. For the purposes of this investigation, it was simply dumped overboard. In any practical wave rotor topping application, this bleed flow will have to be extracted from the wave rotor itself; however, this is not expected to significantly change the dynamic results.

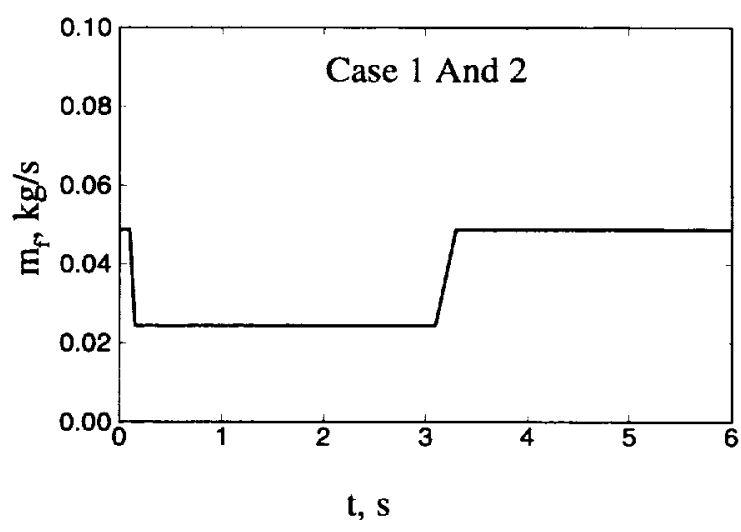

Figure 3 Fuel mass flow rate schedule for Case 1 and 2

Transient Simulation Results and Discussion Two transient operations were simulated. The first involved rapid change in the fuel flow rate. The second involved a rapid drop in the compressor inlet pressure brought about by augmenting the simulation configurations with an idealized valve upstream of the compressor face.

For the results to be presented, a brief word about the case nomenclature is in order. As previously stated, Case 1 and Case 2, designate the wave rotor and control (untopped) engines respectively. The different modes of transient operation are designated by a letter following the case number. "FS" designates the varying fuel schedule operation, and " $\mathrm{V}$ " designates the valve generated compressor inlet disturbance.

\section{Varying Fuel Flow Rate}

The fuel flow schedule used for this transient simulation is shown in Fig.3. The same fuel schedule was used for Case 1 and 2. The design point fuel flow rate for both Case 1 and Case 2 was $0.049 \mathrm{~kg} / \mathrm{s}$. The simulation was run at steady state for $0.1 \mathrm{sec}$. The fuel flow rate $\left(\mathrm{m}_{\mathrm{f}}\right)$ was then rapidly ramped down to $50 \%$ of nominal over a period of 0.05 sec., held at that value for 3 seconds, then increased back to the design point value over a period of $0.25 \mathrm{sec}$., and held there for the duration of the 6.0 second simulation.

Time traces of pressure throughout the engine, for both Case 1 and Case 2 are shown in Fig. 4. Combustor exit and high pressure turbine inlet temperatures are shown in Fig. 5 (they are coincident in the Case 2 configuration). Mass flow rates at several locations are shown in Fig. 6. In general, all of these figures indicate that engine response time was comparable for both Case 1 and 2 and in both cases the response was stable. 

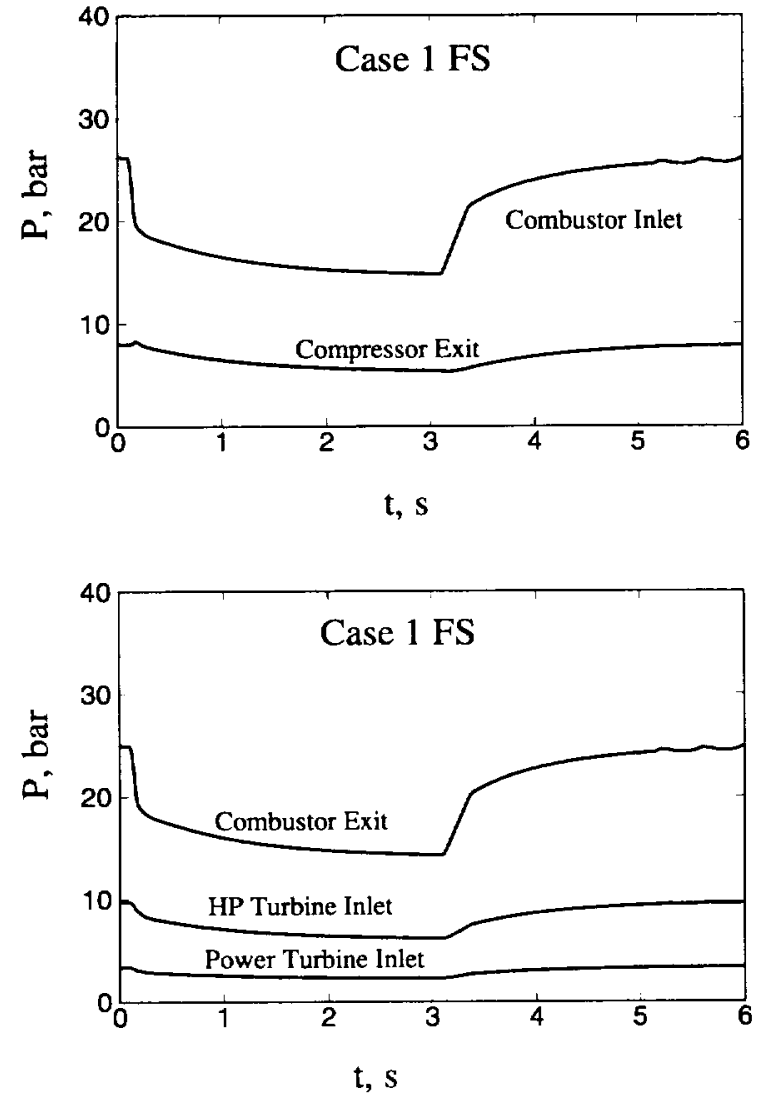

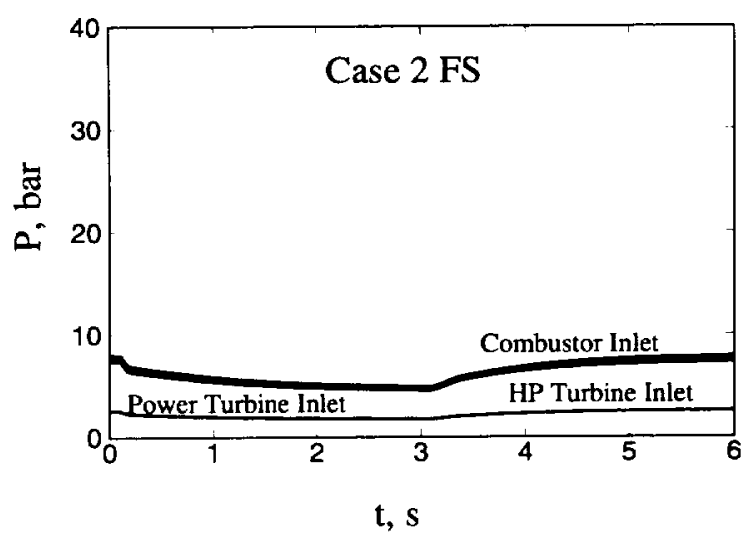

(b)

(a)

Figure 4 Time traces of stagnation pressure at various locations of the engine for the fuel flow transient: (a) wave rotor topped turboshaft engine (CASE 1); (b) non-topped engine (CASE 2)

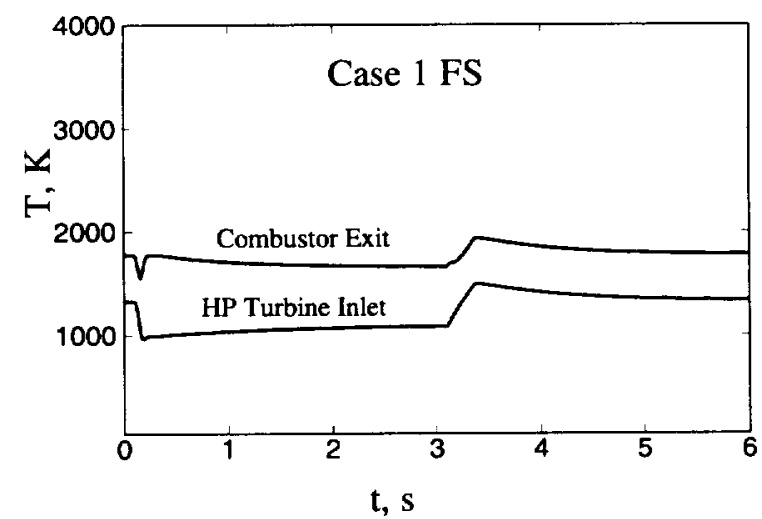

(a)

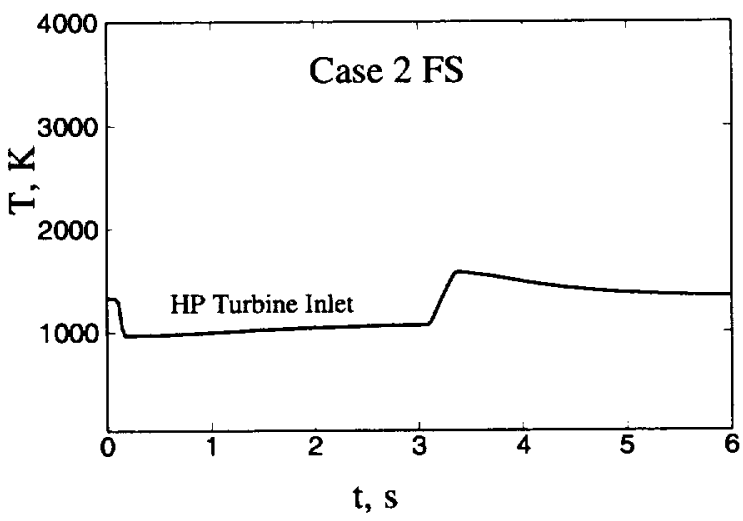

(b)

Figure 5 Time traces of combustor exit and high pressure turbine inlet stagnation temperature for the fuel flow transient: (a) wave rotor topped turboshaft engine (CASE 1); (b) non-topped engine (CASE 2) 


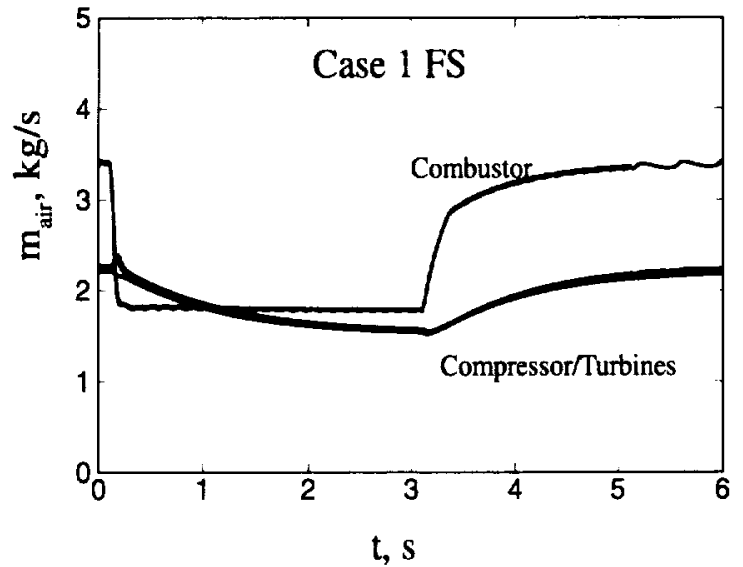

(a)

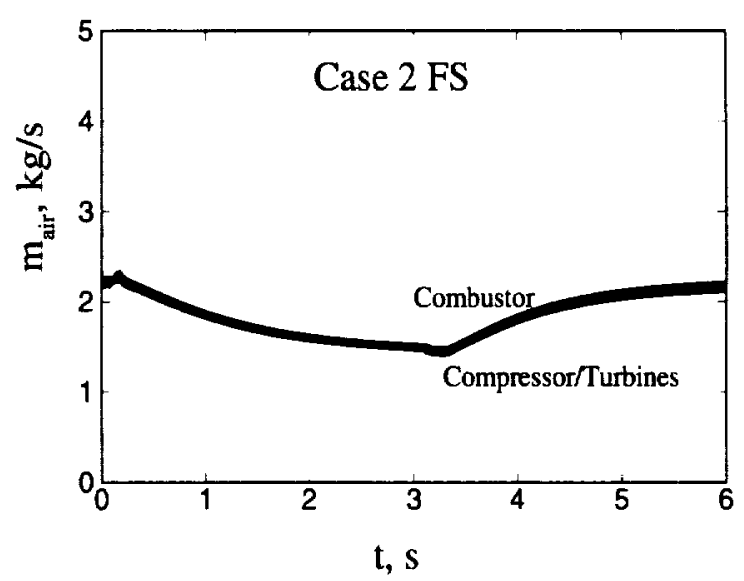

(b)

Figure 6 Time traces of air mass flow at various locations for the fuel flow transient: (a) wave rotor topped turboshaft engine (CASE 1); (b) non-topped engine (CASE 2)

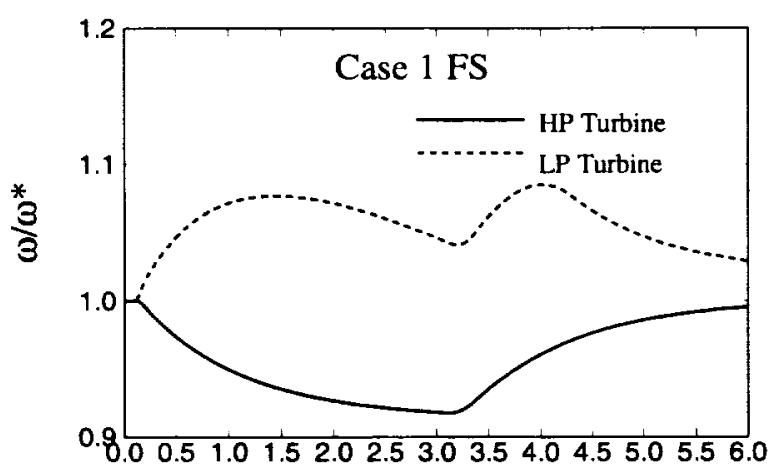

t, s

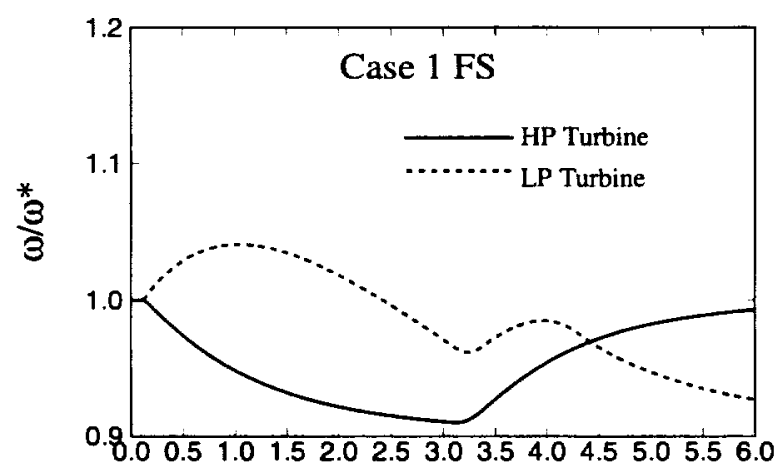

$\mathrm{t}, \mathrm{s}$

(b)

Figure 7 Time traces of spool angular velocities for the fuel flow transient: (a) wave rotor topped turboshaft engine (CASE 1); (b) non-topped engine (CASE 2)

Spool rotational speeds are plotted in Fig.7 as fractions of the design point value. The equilibrium values for rotational speeds were $5340 \mathrm{rad} . / \mathrm{s}$ for the high pressure turbine-compressor spool, and $3500 \mathrm{rad} . / \mathrm{s}$ for the power turbine spool. It is noted that the load placed on the low pressure power turbine essentially followed the fuel flow schedule except the bounds were between $40 \%$ and $100 \%$ of the design value, and the ramp back up from low to high load was delayed until $1.0 \mathrm{sec}$. after the fuel flow rate was increased. Note that the high pressure spools responded identically in both Case 1 and 2; however, the power turbine spools were quite different. For the wave rotor topped case, the power turbine was consistently running above the design speed. The nontopped power turbine spool ran below the design value for a significant portion of the transient. The reason for the difference in behavior is probably due to the fact that at $50 \%$ of design fuel flow rate the power turbine of the wave rotor-topped engine can deliver $40 \%$ of design load at steady state. The non-topped engine can only deliver $28 \%$ of design point power at the $50 \%$ fuel flow rate. Nonetheless, the transient result implies that the wave rotor topped engine configuration has a better available shaft power response than the untopped engine.

Significant differences between the wave rotor topped simulation and the non-topped simulation can be seen when the trajectory of the compressor pressure ratio $(\Pi)$ versus corrected mass flow $\left(\mathrm{m}_{\mathrm{C}}\right)$ is plotted for each case. This has been done in Fig. 8. As with many conventional turboshaft engines, the deceleration response (e.g. reduced fuel flow) of the non-topped Case 1 compressor at first follows a line of constant rotational speed, away from the surge line, then moves along a nearly straight line until a new steady state operating point is reached. During acceleration, the response is similar except the initial trajectory is toward 


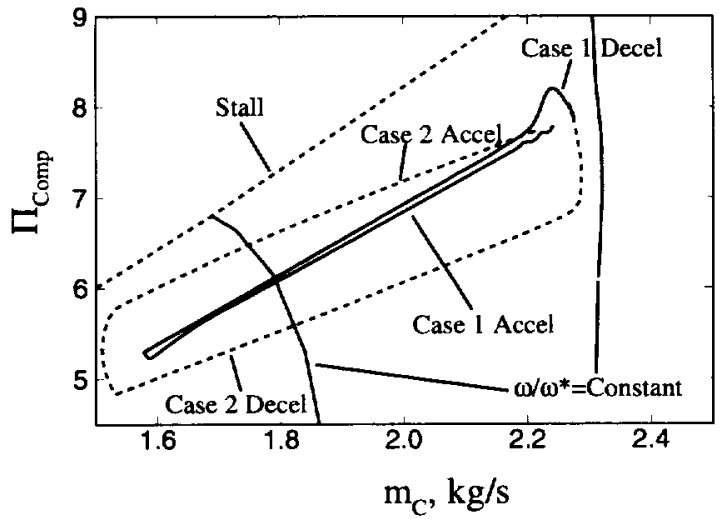

Figure 8 Compressor pressure ratio as a function of corrected mass flow during the fuel flow transient

the surge line at constant rotational speed. This behavior means that the engine acceleration must be limited in order to avoid surge or rotating stall instabilities. The wave rotor-topped engine, on the other hand, traces a completely different trajectory. During deceleration, the compressor moves along a constant speed line, slightly toward the surge line, then it essentially parallels the surge line to the new steady state operating point. During acceleration, the response is essentially a mirror image, with initial trajectory away from the speed line. Overall then, Fig. 8 indicates significant enhancement for the wave rotor-topped engine in overall compressor stability during fuel flow transients

\section{Valve Generated Compressor Inlet Disturbance}

The objective of this transient was to examine the response of the two engine configurations to a rapid change in compressor inlet pressure. The inlet pressure change was implemented by adding an ideal valve upstream of the compressor face. The simulation was run at steady state, with the valve fully open for 0.1 seconds, the valve opening was then instantaneously reduced to $20 \%$ of its fully open area and held there for the duration of the 3.0 second simulation.

Pressure and mass flow rates at various engine locations are shown in Figs. 9 and 10. Although the response times of the two configurations were similar in this case, the amplitudes of the Case 1 were larger than Case 2.

Rotor speed responses are shown in Fig. 11. Again, it is seen that the changes in the wave rotor-topped engine were significantly larger than the untopped engine. It is noted that neither case actually reaches steady state. The load on the power turbine was maintained at the design value for both Casel and Case2. As such, the power turbine continually decelerates throughout the transient.

As in the fuel flow transient, a plot was made of the trajectory of the compressor pressure ratio versus corrected mass flow. This is shown in Fig. 12. In this case, the wave rotor-topped engine produced a curious "loop" in the trajectory which was not seen in the untopped engine. The trajectory for the wave rotor topped transient moved closer to the surge line than did the non-topped case. However, it can be seen that little surge margin is required for both topped and nontopped transients. The explanation for this behavior is unclear.

\section{Concluding Remarks}

In conclusion several facts need to be noted regarding the simulation itself. The first was that the two codes were successfully merged despite the mixture of implicit and explicit solution techniques. This was possible and in fact, easy, due to the modular structure of the GETRAN code and its use of iteration upon solely the plena conditions. Future mergers between explicit 2-D and 3-D simulation routines and GETRAN could be possible in the future. The one disadvantage of the code integration was that it was very computationally intensive. Further research is necessary to improve the computational speed of the merged code.

The wave rotor topped engine appeared robust and quick to respond to transient operations. In particular, the wave rotor topped engine demonstrated little tendency toward surge during rapid fuel flow changes.

During rapid inlet pressure perturbation transients, the compressor of the wave rotor topped engine moved closer to the surge line than the non-topped compressor, but was well within the surge margin.

Computed steady state performance of the wave rotor topped engine compared favorably with the results from previous studies using cycle deck calculations and wave rotor maps. ${ }^{1}$

\section{Acknowledgement}

The third author would like to express his sincere thanks and appreciations to Mr. Carl Lorenzo of the Advanced Controls and Dynamics Branch, and to the Administration of the NASA Lewis Research Center for their continuous cooperation in and support of the GETRAN project. 


\section{References}

1. Welch, G. E., Jones, S. M., Paxson, D. E., "WaveRotor-Enhanced Gas Turbine Engines,"Journal of Engineering for Gas Turbines and Power, Vol. 119, No. 2, 1997, pp. 469-477; also NASA TM106998, July, 1995.

2. Jones, S. M., Welch, G. E., "Performance Benefits for Wave Rotor-Topped Gas Turbine Engines," ASME 96-GT-075, June, 1996; also NASA TM107193, June, 1996.

3. Wilson, J., Paxson, D. E., "Wave Rotor Optimization for Gas Turbine Engine Topping Cycles," Journal of Propulsion and Power, Vol. 12, No. 4, 1996, pp. 778-785; also NASA TM106951 , May, 1995.

4. Paxson, D. E., "A Numerical Model for Dynamic Wave Rotor Analysis," Journal of Propulsion and Power, Vol. 12, No. 5, 1996, pp. 949-957; also

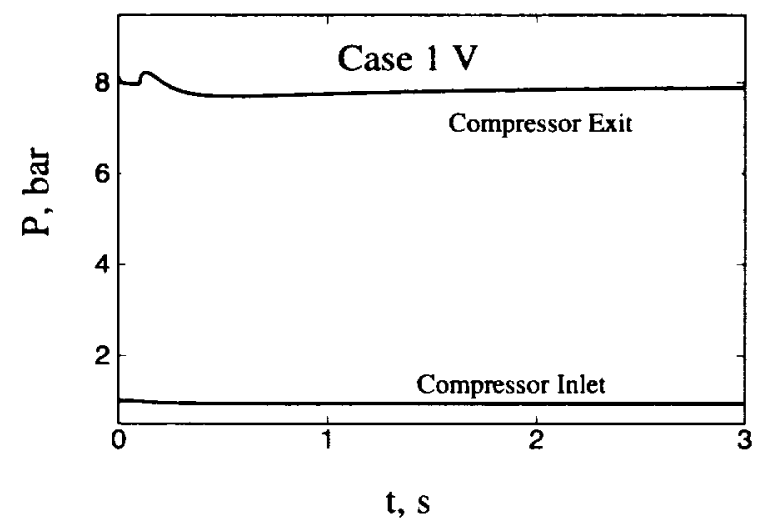

(a)
NASA TM-106997, July, 1995.

5. Snyder, P. H., Fish, R. E., "Assessment of a Wave Rotor Topped Demonstrator Gas Turbine Engine Concept," ASME 96-GT-041, June, 1996.

6. Schobeiri, T., Abouelkheir, M., Lippke, C., "GETRAN: A Generic, Modularly Structured Computer Code for the Simulation of Dynamic Behavior of Aero- and Power Generation Gas Turbines," ASME 93-GT-388, May, 1993.

7. Schobeiri, M.T., Attila, M., and Lippke, C., "GETRAN: The Modularly Structured Computer Code for Simulation of the Transient Behavior of Single and Multi-spool Aero and Power Generation Gas Turbine Engines," Final Report of Cooperative Agreement NAG-1144, Vol. 1-3, December, 1995.

8. Plencner, R. and Snyder, C., "The Navy/NASA Engine Program (NNEP89)-A User's Manual," NASA TM-105186, 1991.

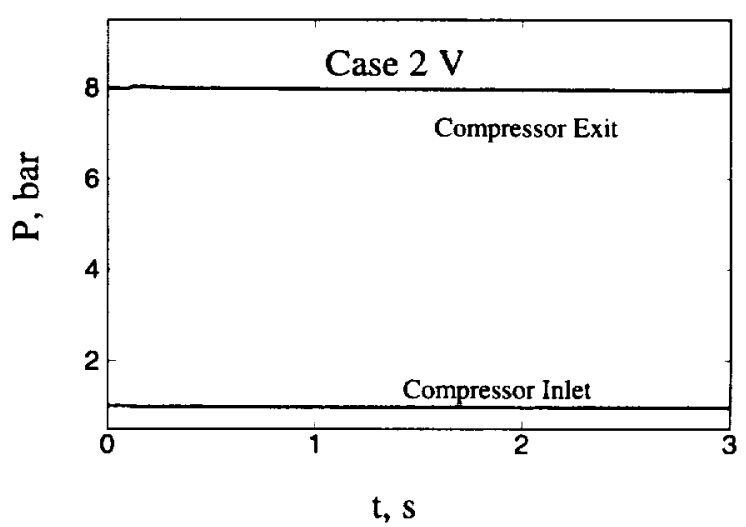

(b)

Figure 9 Time traces of Compressor inlet and exit stagnation pressures for the valve generated compressor inlet disturbance transient: (a) wave rotor topped turboshaft engine (CASE 1); (b) non-topped engine (CASE 2). 


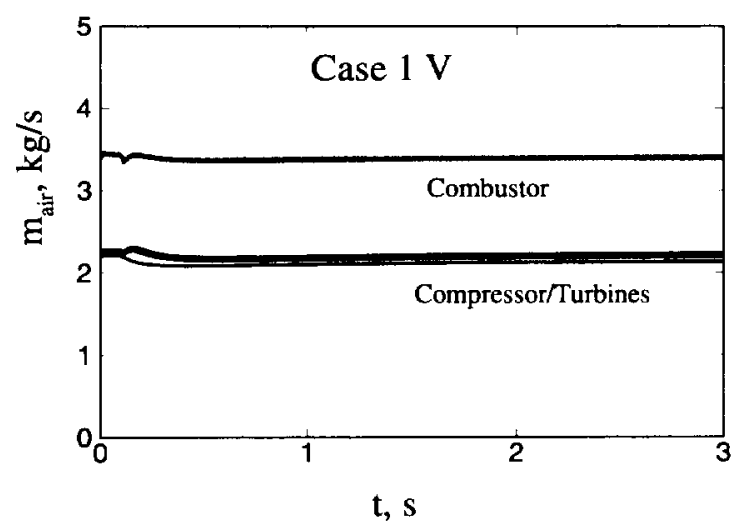

(a)

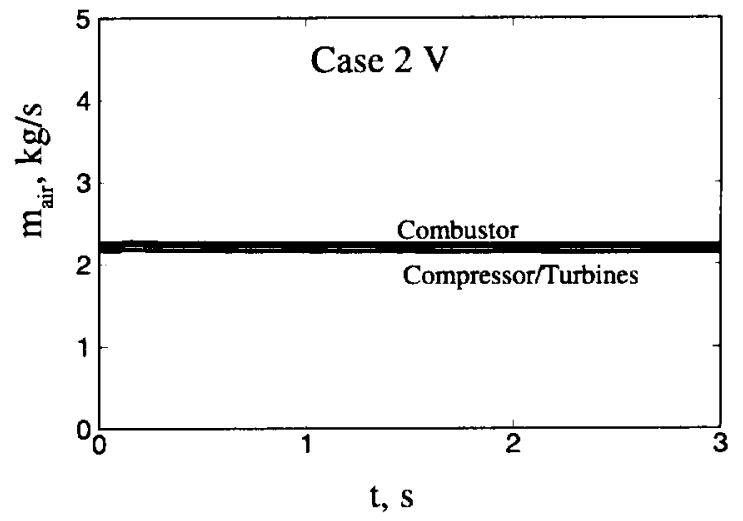

(b)

Figure 10 Time traces of air mass flow at various locations of the engine for the valve generated compressor inlet disturbance transient: (a) wave rotor topped turboshaft engine (CASE 1); (b) non-topped engine (CASE 2).

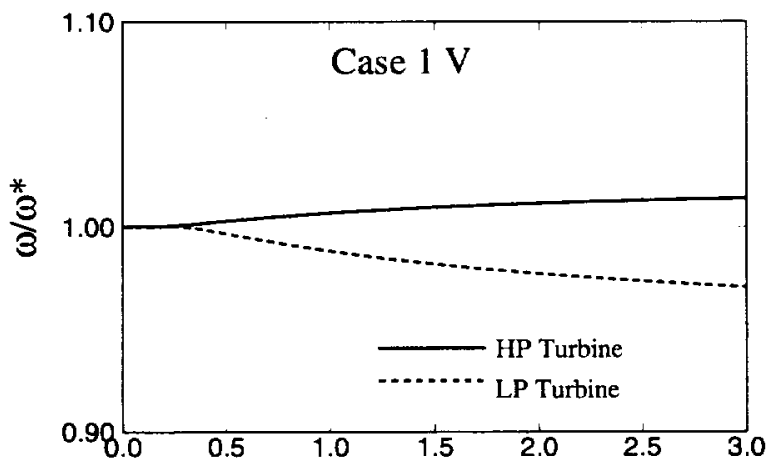

$\mathrm{t}, \mathrm{s}$

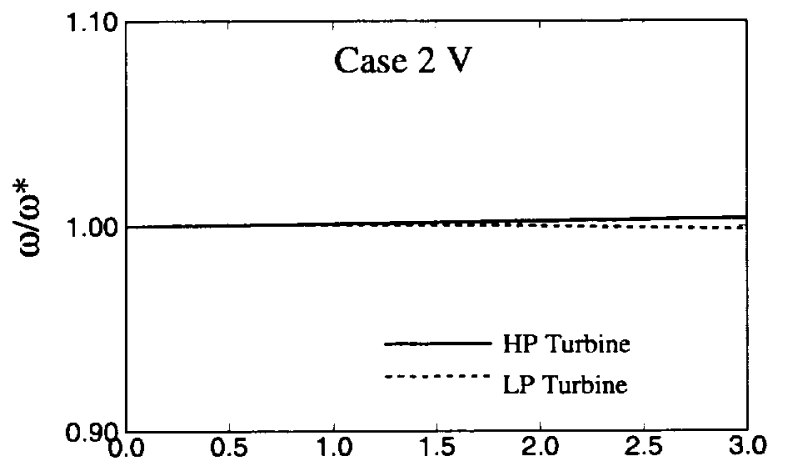

$\mathrm{t}, \mathrm{s}$

(b)

Figure 11 Time traces of spool angular velocities for the valve generated compressor inlet disturbance transient: (a) wave rotor topped turboshaft engine (CASE 1); (b) non-topped engine (CASE 2).

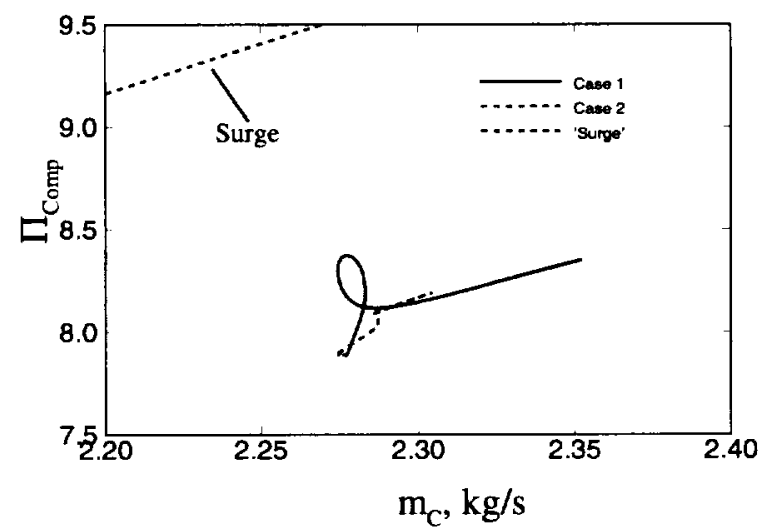

Figure 12 Compressor pressure ratio as a function of corrected mass flow during the valve generated compressor inlet disturbance transient. 
Public reporting burden for this collection of information is estimated to average 1 hour per response, including the time for reviewing instructions, searching existing data sources, gathering and maintaining the data needed, and completing and reviewing the collection of information. Send comments regarding this burden estimate or any other aspect of this collection of information, including suggestions for reducing this burden, to Washington Headquarters Services, Directorate for Information Operations and Reports, 1215 Jefter
Davis Highway, Suite 1204, Arlington, VA 22202-4302, and to the Office of Management and Budget, Papenwork Reduction Project (0704-0188), Washington, DC 20503.

\begin{tabular}{|l|c|c|}
\hline 1. AGENCY USE ONLY (Leave blank) & $\begin{array}{c}\text { 2. REPORT DATE } \\
\text { July } 1997\end{array}$ & $\begin{array}{r}\text { 3. REPORT TYPE AND DATES COVERED } \\
\text { Technical Memorandum }\end{array}$ \\
\hline
\end{tabular}

4. TITLE AND SUBTITLE

Dynamic Simulation of a Wave Rotor Topped Turboshaft Engine
5. FUNDING NUMBERS

WU-523-26-33

6. AUTHOR(S)

R.B. Greendyke, D.E. Paxson, and M.T. Schobeiri

7. PERFORMING ORGANIZATION NAME(S) AND ADDRESS(ES)

B. PERForming ORgANIZATION REPORT NUMBER

National Aeronautics and Space Administration

Lewis Research Center

Cleveland, Ohio 44135-3191

E-10816

9. SPONSORINGMONITORING AGENCY NAME(S) AND ADDRESS(ES)

10. SPONSORINGMONITORING AGENCY REPORT NUMBER

National Aeronautics and Space Administration

Washington, DC 20546-0001

NASA TM-107514

AIAA-97-3143

11. SUPPLEMENTARY NOTES

Prepared for the 33rd Joint Propulsion Conference and Exhibit cosponsored by AIAA, ASME, SAE, and ASEE, Seattle, Washington, July 6-9, 1997. R.B. Greendyke and M.T. Schobeiri, Texas A\&M University, College Station, Texas 77843; D.E. Paxson, NASA Lewis Research Center. Responsible person, D.E. Paxson, organization code 5530, (216) 433-8334.

12a. DISTRIBUTION/AVAILABILTTY STATEMENT

12b. DISTRIBUTION CODE

Unclassified - Unlimited

Subject Category 07

This publication is available from the NASA Center for AeroSpace Information, (301) 621-0390.

13. ABSTRACT (Maximum 200 words)

The dynamic behavior of a wave rotor topped turboshaft engine is examined using a numerical simulation. The simulation utilizes an explicit, one-dimensional, multi-passage, CFD based wave rotor code in combination with an implicit, one-dimensional, component level dynamic engine simulation code. Transient responses to rapid fuel flow rate changes and compressor inlet pressure changes are simulated and compared with those of a similarly sized, untopped, turboshaft engine. Results indicate that the wave rotor topped engine responds in a stable, and rapid manner. Furthermore, during certain transient operations, the wave rotor actually tends to enhance engine stability. In particular, there is no tendency toward surge in the compressor of the wave rotor topped engine during rapid acceleration. In fact, the compressor actually moves slightly away from the surge line during this transient. This behavior is precisely the opposite to that of an untopped engine. The simulation is described. Issues associated with integrating CFD and component level codes are discussed. Results from several transient simulations are presented and discussed.

\begin{tabular}{|c|c|}
\hline 14. SUBJECT TERMS \\
Wave rotor; Simulation; CFD \\
\hline $\begin{array}{c}\text { 17. SECURITY CLASSIFICATION } \\
\text { OF REPORT } \\
\text { Unclassified }\end{array}$ & $\begin{array}{c}\text { 18. SECURITY CLASSIFICATION } \\
\text { OF THIS PAGE } \\
\text { Unclassified }\end{array}$ \\
\hline
\end{tabular}

\begin{tabular}{|c|c|}
\hline & $\begin{array}{c}\text { 15. NUMBER OF PAGES } \\
11\end{array}$ \\
\hline & $\begin{array}{r}\text { 16. PRICE CODE } \\
\text { A03 }\end{array}$ \\
\hline $\begin{array}{l}\text { 19. SECUAITY CLASSIFICATION } \\
\text { OF ABSTRACT } \\
\text { Unclassified }\end{array}$ & 20. LIMITATION OF ABSTRACT \\
\hline
\end{tabular}

